\title{
Hydrogen-rich Syngas Production via Catalytic Gasification of Sewage Sludge and Wheat Straw Using Corn Stalk Char-supported Catalysts
}

Shuang Shang, Chaoqiang Guo, Kui Lan, Zeshan Li, Weitao He, Zhenhua Qin, and Jianfen $\mathrm{Li} *$

The co-gasification of wheat straw and wet sewage sludge for hydrogenrich gas production was investigated in a fixed bed reactor with corn stalk char (CSC)-supported catalysts. The Ni/CSC, Ni-Fe/CSC, and Ni-Fe$\mathrm{La} / \mathrm{CSC}$ catalysts were characterized via ultimate analysis, X-ray fluorescence, thermogravimetric, X-ray diffraction, X-ray photoelectron spectroscopy, scanning electron microscopy, Brunauer-Emmett-Teller, and Fourier transform infrared spectroscopy analyses. A series of experiments were performed to explore the effects of reactor temperature, catalyst type, moisture content of wet sludge, and catalyst recycling performance on the composition and yield of gasification gases. The experiments demonstrated that the nickel-iron alloy ( $\left.\mathrm{Fe}_{0.64} \mathrm{Ni}_{0.36}\right)$ was detected in the Ni-Fe-La/CSC catalyst, and the Ni-Fe-La/CSC catalyst showed much higher hydrogen production compared with the Ni/CSC and $\mathrm{Ni}-\mathrm{Fe} / \mathrm{CSC}$ catalysts. Furthermore, $\mathrm{La}_{2} \mathrm{O}_{3}$ effectively maintained the catalytic performance of the catalyst by relieving carbon deposition. Compared with non-catalyst biomass gasification, $\mathrm{H}_{2}$ yield increased from $3.80 \mathrm{~mol} / \mathrm{kg}$ to $11.96 \mathrm{~mol} / \mathrm{kg}$ using Ni-Fe-La/CSC catalyst at $600^{\circ} \mathrm{C}$. The newly developed tri-metallic $\mathrm{Ni}-\mathrm{Fe}-\mathrm{La} / \mathrm{CSC}$ catalyst exhibited high catalytic activity for biomass gasification at low temperature.

Keywords: Gasification; Sewage Sludge; Wheat Straw; Char; Catalyst; Syngas

Contact information: School of Chemical and Environmental Engineering, Wuhan Polytechnic University, Wuhan 430023, China; *Corresponding author: lijfen@163.com

\section{INTRODUCTION}

At present, energy, environment, and economy are three issues that all need to be simultaneously considered. Hydrogen is a type of pollution-free energy that can reduce the reliance on oil, and it is expected to play an important role in the future energy structure. However, most of current hydrogen production is based on fossil fuel reforming (Arregi et al. 2018), which will release a large amount of carbon dioxide and other greenhouse gases. Therefore, it is necessary to find clean energy and renewable energy to replace fossil fuels.

Biomass is a renewable material that can be converted into solid, liquid, and gas fuels through chemical processes. The use of biomass as a fuel is a carbon neutral process. The released amount of carbon dioxide is equal to the absorbed amount of carbon dioxide via photosynthesis during the growth process, so the net emission of carbon dioxide is approximately zero. A large number of studies have indicated that hydrogen production via biomass gasification is an attractive and promising technology. Of all the thermochemical processes, steam gasification is considered to be one of the most effective techniques of generating hydrogen from biomass (Sikarwar et al. 2016). However, a large portion of biomass that is available for use has a high moisture content. Recently, supercritical water 
gasification (SCWG) has been proposed as an alternative to steam gasification for high moisture content biomass in favor of avoiding high drying costs (Arregi et al. 2018). Zeng et al. (2017) compared the difference between wet biomass self-moisture gasification (BSMG) and conventional biomass steam gasification (BSG). The results show that the water diffusion of the BSMG is spontaneous in high temperature, which leads to an increase in gas production. However, the water diffusion of BSG consumes some energy, which reduces gas production. Many researchers have studied the co-gasification of dry biomass and wet biomass used with high moisture content (Zhu et al. 2018). Akkache et al. (2016) conducted a feasibility study on the co-gasification of wastewater sludge and different feedstock. This work has shown that the concerns related to sludge gasification (pollutant release and ash fusibility) can be overcome by using the appropriate technology.

In the process of biomass gasification, a large amount of tar in the gas phase will condense at low temperature, blocking the downstream pipeline of the process, thus increasing the process cost. In addition, tar can cause a lot of energy loss and some environmental problems related to tar (Han and Kim 2008). Tar is usually highly corrosive, and its composition is complex. It is mainly composed of some toxic and harmful substances such as polycyclic aromatic hydrocarbons (PAH) and aromatic compounds (Valderrama Rios et al. 2018). One of the most effective techniques for removing tar is to convert it into useful gases by catalytic steam reforming, so various catalysts have been developed. Among them, metal nickel can break $\mathrm{C}-\mathrm{C}$ and $\mathrm{C}-\mathrm{H}$ bonds, and Ni-based catalysts are attractive in tar reforming because of their strong catalytic performance and relatively low cost. However, Ni-based catalysts are susceptible to deactivation by carbon deposition and coking during catalytic cracking. Therefore, some researchers improved the catalytic performance of Ni-based catalyst through the addition of additives such as $\mathrm{Fe}, \mathrm{Co}$, $\mathrm{Cu}, \mathrm{Mg}, \mathrm{Ce}$, etc. Liu et al. (2010) modified the Ni/PG catalyst by adding additives (Fe, $\mathrm{Mg}$, $\mathrm{Mn}$, and $\mathrm{Ce}$ ), and the results showed that Fe was the best additive for promoting the catalytic performance of Ni/PG both in tar conversion and $\mathrm{H}_{2}$ yield. When the Fe loading was increased to $8 \mathrm{wt} \%$, tar conversion was $98.2 \%$. The traditional catalyst supports are mainly natural ores such as dolomite, olivine, and other similar ores (He et al. 2009).

In recent years, biochar has received increased attention due to its high specific surface area, acidic groups, and surface oxygen-containing functional groups, which play an important role in the catalytic activity of the catalyst. Biochar could effectively adsorb the light tar compounds, such as volatile organic compounds (VOCs), and the charsupported catalysts could be gasified to recover energy of char without the need for frequent regeneration after deactivation (Shen et al. 2016). Al-Rahbi and Williams (2017) used tire char as a catalyst for hydrogen-rich syngas production and tar reduction. Hu et al. (2018) prepared $\mathrm{Ni} /$ char catalysts by using pine sawdust char as catalyst support. The results show that the char-supported nickel catalysts have high catalytic activity in biomass gasification and tar removal. Moreover, biochar also contains alkali metals and alkaline earth metals that have a certain catalytic effect. Hu et al. (2015) indicated that alkaline and alkaline earth metals (AAEMs) could enhance the production of $\mathrm{H}_{2}$ and $\mathrm{CO}_{2}$ during biomass pyrolysis by promoting the main hydrogen production reactions such as the Boudouard reaction, the water gas shift reaction, etc. Yao et al. (2016) used wheat straw char (WC), rice husk char (RC), and cotton stalk char (CC) as catalyst supports to prepare $\mathrm{Ni} / \mathrm{CC}, \mathrm{Ni} / \mathrm{RC}$, and $\mathrm{Ni} / \mathrm{WC}$ catalysts. The experimental results indicated that the $\mathrm{Ni} / \mathrm{CC}$ catalyst showed much higher hydrogen production compared with $\mathrm{Ni} / \mathrm{RC}$ and $\mathrm{Ni} / \mathrm{WC}$ catalysts, due to the higher content of alkali and alkaline earth metals and the much higher external surface area.

Shang et al. (2020). "Catalytic gasification of biomass," BioResources 15(2), 4294-4313. 4295 
This work aims to enhance hydrogen-rich syngas production from biomass gasification by preparing high-efficiency catalysts to support the corn stalk char. The $\mathrm{Ni} / \mathrm{CSC}$, Ni-Fe/CSC, and Ni-Fe-La/CSC catalysts were synthesized using the homogeneous precipitation method and applied to the co-gasification of wet sludge and straw. The catalysts were characterized by ultimate analysis, X-ray fluorescence (XRF), thermogravimetric (TG), X-ray diffraction (XRD), X-ray photoelectron spectroscopy (XPS), scanning electron microscopy (SEM), the Brunauer-Emmett-Teller (BET) method, and Fourier transform infrared (FTIR) spectroscopy to explore the mechanism of the catalyst. A series of experiments were performed to explore the effects of reactor temperature, catalyst type, moisture content of wet sludge, and catalyst recycling performance on the composition and yield of gasification gases. Meanwhile, a non-catalyst was also studied as the baseline for comparison.

\section{EXPERIMENTAL}

\section{Materials}

The wet sewage sludge used in this study was collected from a domestic sewage treatment plant in Wuhan, Hubei Province, China. The sludge was dried at $105{ }^{\circ} \mathrm{C}$ for 24 $\mathrm{h}$ in the oven to ensure that their mass was constant. Dry sludge was blended uniformly with a certain amount of water to obtain the wet sludge with different moisture contents. The wheat straw and corn stalk selected around Wuhan, China were pulverized to the size of $0.3 \mathrm{~mm}$ to $4.0 \mathrm{~mm}$ with a small crusher to eliminate the influence of the particle size on the experimental results. Corn stalk was used to prepare the chars. The biomass sample obtained by mixing wheat straw and wet sludge was used as the raw material for hydrogenrich syngas production. The proximate and ultimate analyses of dry sludge, wheat straw, and corn stalk are listed in Table 1 and presented on an air-dried basis.

Table 1. Proximate and Ultimate Analysis of Sewage Sludge, Wheat Straw, and Corn Stalk

\begin{tabular}{|c|c|c|c|c|c|c|c|c|c|}
\hline \multirow{2}{*}{ Sample } & \multicolumn{4}{|c|}{ Proximate Analysis (wt\%) } & \multicolumn{4}{c|}{ Ultimate Analysis (wt\%) } \\
\cline { 2 - 9 } & $M^{\text {dd }}$ & $A^{\text {ad }}$ & $V^{\text {ad }}$ & $\mathrm{FC}^{\text {ad }}$ & $\mathrm{C}$ & $\mathrm{H}$ & $\mathrm{N}$ & $\mathrm{S}$ & $\mathrm{O}^{\mathrm{c}}$ \\
\hline Sewage Sludge & 4.15 & 50.69 & 35.33 & 9.83 & 25.20 & 5.62 & 3.82 & 0.15 & 14.52 \\
\hline Wheat Straw & 10.88 & 6.91 & 67.11 & 15.10 & 31.04 & 4.22 & 0.40 & 0.06 & 57.37 \\
\hline Corn Stalk & 11.37 & 8.12 & 68.13 & 12.38 & 32.43 & 4.41 & 0.05 & 0.87 & 54.11 \\
\hline
\end{tabular}

M (Moisture); A (Ash); V (Volatile); FC (Fixed carbon); ${ }^{\text {ad }}$ Air-dried; ${ }^{\circ}$ Calculated by difference (O\% $=100 \%-$ Ash $\%-$ C $\%-H \%-\mathrm{N} \%-\mathrm{S} \%)$

\section{Methods}

\section{Catalysts preparation}

The corn stalk char (CSC) was prepared by pyrolyzing corn stalk under nitrogen atmosphere. The reactor temperature was raised from ambient temperature to $500{ }^{\circ} \mathrm{C}$ at 10 ${ }^{\circ} \mathrm{C} / \mathrm{min}$, and then held at $500{ }^{\circ} \mathrm{C}$ for $1 \mathrm{~h}$. The corn stalk char was soaked in potassium hydroxide solution for $24 \mathrm{~h}$ to eliminate tar. The mass ratio of char to potassium hydroxide was 3:1. Then, the corn stalk char was washed with deionized water several times followed by oven drying $\left(105^{\circ} \mathrm{C}\right)$.

The Ni/CSC, Ni-Fe/CSC, and Ni-Fe-La/CSC catalysts were prepared by the homogeneous precipitation method using $\mathrm{Ni}\left(\mathrm{NO}_{3}\right)_{2} \cdot 6 \mathrm{H}_{2} \mathrm{O}, \mathrm{Fe}\left(\mathrm{NO}_{3}\right)_{3} \cdot 9 \mathrm{H}_{2} \mathrm{O}$, and 
$\mathrm{La}\left(\mathrm{NO}_{3}\right)_{3} \cdot 6 \mathrm{H}_{2} \mathrm{O}$ as nickel, iron, and lanthanum precursors, respectively. Proportions of 30 wt $\%$ of $\mathrm{Ni}, 15 \mathrm{wt} \%$ of $\mathrm{Ni}$ and $\mathrm{Fe}$, and $10 \mathrm{wt} \%$ of Ni, Fe, and La were loaded on corn stalk char to prepare $30 \% \mathrm{Ni} / \mathrm{CSC}, 15 \% \mathrm{Ni}-15 \% \mathrm{Fe} / \mathrm{CSC}$, and $10 \% \mathrm{Ni}-10 \% \mathrm{Fe}-10 \% \mathrm{La} / \mathrm{CSC}$ catalysts, respectively. A certain proportion of $\mathrm{Ni}\left(\mathrm{NO}_{3}\right)_{2} \cdot 6 \mathrm{H}_{2} \mathrm{O}, \mathrm{Fe}\left(\mathrm{NO}_{3}\right)_{3} \cdot 9 \mathrm{H}_{2} \mathrm{O}$, $\mathrm{La}\left(\mathrm{NO}_{3}\right)_{3} \cdot 6 \mathrm{H}_{2} \mathrm{O}$, and treated corn stalk char were added in a $500-\mathrm{mL}$ flask. Then, $4 \mathrm{~g}$ potassium hydroxide as precipitant and $400 \mathrm{~mL}$ distilled water were added. The blend was stirred at $115^{\circ} \mathrm{C}$ for $4 \mathrm{~h}$. After filtering and drying overnight at $105^{\circ} \mathrm{C}$, the char-supported catalysts were devolatilized in a flowing nitrogen atmosphere from ambient temperature to $900{ }^{\circ} \mathrm{C}$ at $10{ }^{\circ} \mathrm{C} / \mathrm{min}$, and then they were held at $900{ }^{\circ} \mathrm{C}$ for $2 \mathrm{~h}$ before storage and further use.

\section{Apparatus and procedure for biomass gasification}

The experiments were performed using a fixed bed reactor facility, as shown in Fig. 1. The biomass samples and quartz wool (Daiermeng Science and Technology, Wuxi, China) containing $2 \mathrm{~g}$ of catalyst were placed in a porcelain boat. Before the experiment, high-purity nitrogen gas was introduced into the quartz tube for $30 \mathrm{~min}$ to exhaust the air in the quartz tube. The holding time was set to $10 \mathrm{~min}$. Once the desired temperature was reached, the heating furnace was pushed to the position where the sample was located, and it was instantly gasified at the specified temperature. The non-condensable gases were collected with a gas collecting bag and the volume of produced gas was measured by a gas flow meter. The composition and content of the gas were measured by a gas analyzer.

Using $2.5 \mathrm{~g}$ of wet sludge with a moisture content of $60 \mathrm{wt} \%$ and $1 \mathrm{~g}$ of wheat straw as biomass material, different kinds of catalysts were added and gasified at $600{ }^{\circ} \mathrm{C}, 700$ ${ }^{\circ} \mathrm{C}, 800{ }^{\circ} \mathrm{C}$, and $900{ }^{\circ} \mathrm{C}$, to explore the influence of temperature and catalyst type. A sample of $1 \mathrm{~g}$ of wheat straw was separately mixed with wet sludge (the dry sludge was $1 \mathrm{~g}$ ) with moisture contents of $30 \mathrm{wt} \%, 40 \mathrm{wt} \%, 50 \mathrm{wt} \%, 60 \mathrm{wt} \%, 70 \mathrm{wt} \%$, and $80 \mathrm{wt} \%$, and gasified at $600{ }^{\circ} \mathrm{C}$ using the $\mathrm{Ni}-\mathrm{Fe}-\mathrm{La} / \mathrm{CSC}$ catalyst, to consider the influence of moisture content. A sample of $2.5 \mathrm{~g}$ of wet sludge with a moisture content of $60 \mathrm{wt} \%$ and $1 \mathrm{~g}$ of wheat straw were used as biomass material and gasified at $600{ }^{\circ} \mathrm{C}$. The biomass material was changed after each experiment, and the catalysts were used repeatedly to consider the influence of the catalyst recycling performance.

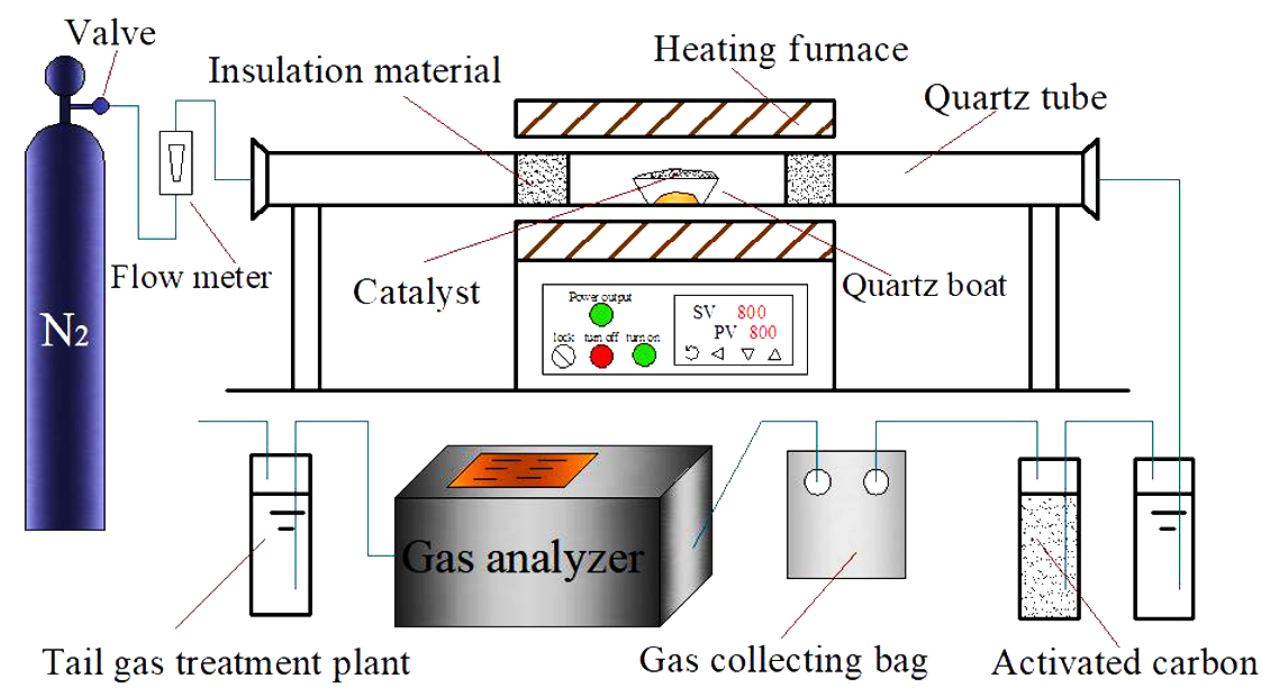

Fig. 1. Schematic diagram of the experimental system 
Analysis

The ultimate analysis of the samples was conducted using a CHNS/O analyzer (FLASH2000, Thermo Fisher Scientific, Waltham, MA, USA). This analysis gave the mass percentages of carbon, hydrogen, nitrogen, and sulfur in the samples simultaneously, and the mass percent of oxygen was determined by difference. The proximate analysis method of coal, according to GB/T 212 (2008), was used to obtain proximate analysis of the sewage sludge, wheat straw, and corn stalk (i.e., moisture, volatile matter, fixed carbon, and ash content of the material). The element composition and material structure of the catalyst were analyzed using an X-ray fluorescence spectrometer (EDX-7000; Shimadzu Corp., Kyoto, Japan) and an X-ray diffractometer (XRD-7000; Shimadzu Corp., Kyoto, Japan). The thermal stability of the support and catalyst were evaluated using a thermogravimetric analyzer (SDT Q600; TA Instruments, New Castle, DE, USA). The XPS analysis (DLD-600W; Shimadzu Corp., Kyoto, Japan) was used to qualitatively analyze the surface elements of the catalyst and their valence states. Scanning electron microscopy (S-3000N; Hitachi, Ltd., Tokyo, Japan) was used to observe the surface morphology of the support and catalyst. Surface area and pore properties of the support and catalyst were determined by a surface area analyzer (ASAP 2020 HD88; Micromeritics Instrument Corp., Norcross, GA, USA). The chemical functional groups in catalyst samples were investigated using FTIR (Nicolet IS10; Thermo Fisher Scientific, Waltham, MA, USA). The gas composition analysis was conducted with an infrared gas analyzer (Gasboard-3100P; Hubei Cubic-Ruiyi Instrument Co., Wuhan, China).

The lower heating value (LHV) of the product gas is defined by Lv et al. (2004) as follows,

$$
\operatorname{LHV}\left(\mathrm{kJ} / \mathrm{Nm}^{3}\right)=\left(27.5 \times \mathrm{H}_{2}+30 \times \mathrm{CO}+85.4 \times \mathrm{CH}_{4}+151.3 \times \mathrm{C}_{\mathrm{n}} \mathrm{H}_{\mathrm{m}}\right) \times 4.2
$$

where $\mathrm{H}_{2}, \mathrm{CO}, \mathrm{CH}_{4}$, and $\mathrm{C}_{\mathrm{n}} \mathrm{H}_{\mathrm{m}}$ are the gas component concentrations of the product gas.

\section{RESULTS AND DISCUSSION}

\section{Characterization of Catalysts}

\section{Ultimate analysis and XRF}

Table 2 shows the components of CSC, Ni/CSC, used Ni/CSC, Ni-Fe/CSC, used $\mathrm{Ni}-\mathrm{Fe} / \mathrm{CSC}, \mathrm{Ni}-\mathrm{Fe}-\mathrm{La} / \mathrm{CSC}$, and used Ni-Fe-La/CSC. It shows that the corn stalk char was mainly composed of $\mathrm{C}, \mathrm{K}, \mathrm{Si}, \mathrm{Ca}$, and $\mathrm{Fe}$. Because the biochar was soaked in a potassium hydroxide solution for $24 \mathrm{~h}$ to remove tar, the K content in the CSC was high. During preparation of the catalysts, potassium decomposed at high temperature, which resulted in low potassium content in the catalysts. According to the results of XRF analysis, nickel, iron, and lanthanum had been successfully loaded on the char support. It could be seen from the ultimate analysis results that the carbon content in the catalyst was lower than that in the char support. Firstly, the char support was prepared for $500{ }^{\circ} \mathrm{C}$, while the catalyst was calcined at $900{ }^{\circ} \mathrm{C}$. Secondly, due to the catalysis of metals, $\mathrm{CO}_{2}$ was formed by $\mathrm{C}$ and $\mathrm{O}$ during the preparation of catalyst, which resulted in the decrease of $\mathrm{C}$ content in the catalyst. Additionally, the $\mathrm{C}$ content in the catalysts increased slightly after reaction. On the one hand, it was caused by carbon deposition on the surface of the catalyst. On the other hand, the oxygen element of metal oxide was removed by the reduction reaction. The mass loss of oxygen element will also increase the carbon content in the catalyst after reaction. 
After the three catalysts were used an equal amount of times, the carbon deposition of Ni$\mathrm{Fe}-\mathrm{La} / \mathrm{CSC}$ catalyst was the least.

Table 2. Ultimate Analysis and XRF Analysis of Seven Samples

\begin{tabular}{|c|c|c|c|c|c|c|c|c|}
\hline \multirow{2}{*}{ Sample } & \multicolumn{7}{|c|}{ Main Composition and Content (\%) } \\
\cline { 2 - 9 } & $\mathrm{C}$ & $\mathrm{H}$ & $\mathrm{Ni}$ & $\mathrm{Fe}$ & $\mathrm{La}$ & $\mathrm{Si}$ & $\mathrm{K}$ & $\mathrm{Ca}$ \\
\hline $\mathrm{CSC}$ & 60.81 & 0.96 & - & 2.99 & - & 10.11 & 11.65 & 9.70 \\
\hline $\mathrm{Ni} / \mathrm{CSC}$ & 42.13 & 0.36 & 44.52 & 0.34 & - & 5.51 & 3.77 & 2.23 \\
\hline Used Ni/CSC & 43.66 & 0.22 & 43.28 & 0.31 & - & 6.07 & 2.73 & 2.03 \\
\hline Ni-Fe/CSC & 43.86 & 0.39 & 23.21 & 21.47 & - & 4.01 & 0.86 & 0.68 \\
\hline Used Ni-Fe/CSC & 44.92 & 0.34 & 22.35 & 20.88 & - & 5.22 & 0.76 & 0.63 \\
\hline Ni-Fe-La/CSC & 43.14 & 0.42 & 13.52 & 13.73 & 15.18 & 4.45 & 4.93 & 1.72 \\
\hline Used Ni-Fe-La/CSC & 43.96 & 0.35 & 13.01 & 13.10 & 14.36 & 4.58 & 3.81 & 1.49 \\
\hline
\end{tabular}

TG analysis

Figure 2 shows the thermogravimetric analysis of char support and char-supported catalysts under the $\mathrm{N}_{2}$ atmosphere. With the test temperature rising from ambient temperature to $900{ }^{\circ} \mathrm{C}$, the mass loss of $\mathrm{Ni} / \mathrm{CSC}$ catalyst and $\mathrm{Ni}-\mathrm{Fe}-\mathrm{La} / \mathrm{CSC}$ catalyst was only about $15 \mathrm{wt} \%$, in which the water loss was $5 \mathrm{wt} \%$. However, the mass loss of the Ni$\mathrm{Fe} / \mathrm{CSC}$ catalyst reached $23 \%$. Consequently, the Ni/CSC catalyst and Ni-Fe-La/CSC catalyst had high thermal stability, while the thermal stability of the Ni-Fe/CSC catalyst was poor. In addition, the mass of char support decreased remarkably with the increase of test temperature, and the maximum mass loss reached $40 \mathrm{wt} \%$ when the temperature was $900{ }^{\circ} \mathrm{C}$. Because the char support was prepared for $500{ }^{\circ} \mathrm{C}$, the mass loss was lower before $500{ }^{\circ} \mathrm{C}$, and the mass of CSC was remarkably reduced after $500{ }^{\circ} \mathrm{C}$.

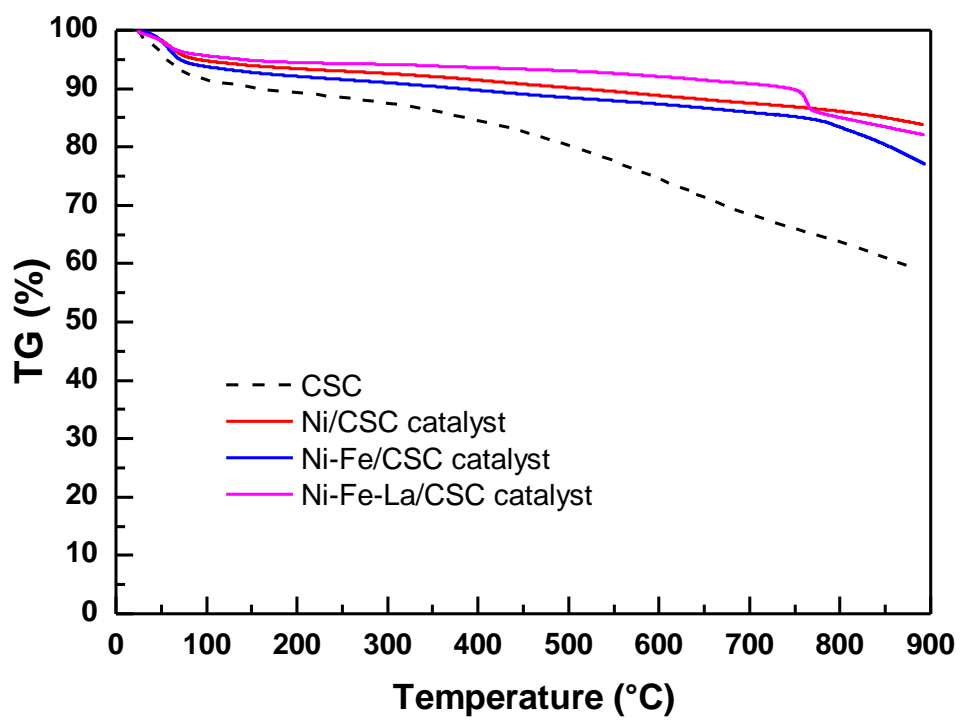

Fig. 2. TG analysis of char support and char-supported catalysts under the $\mathrm{N}_{2}$ atmosphere

\section{XRD analysis}

Figure 3 shows the XRD patterns of char-supported catalysts and used catalysts. The characteristic diffraction peaks of $\mathrm{Ni}(111), \mathrm{Ni}(200)$, and $\mathrm{Ni}(220)$ at $2 \theta=44.2^{\circ}, 51.8^{\circ}$, and $76.1^{\circ}$, respectively, were observed in the Ni/CSC catalyst, which showed a better crystalline structure. Some weak characteristic diffraction peaks of $\mathrm{Fe}_{2} \mathrm{O}_{3}$ were observed 
in the Ni-Fe/CSC catalyst. According to XRF analysis, a certain amount of nickel and iron had been loaded into the $\mathrm{Ni}-\mathrm{Fe} / \mathrm{CSC}$ catalyst. However, the characteristic peaks of $\mathrm{Ni}^{0}$ and $\mathrm{NiO}$ were not found over the Ni-Fe/CSC catalyst, which was attributed to the high dispersion or poor crystallinity of nickel. The strong peak at $2 \theta=41.8^{\circ}, 50.3^{\circ}$, and $72.2^{\circ}$ was observed and identified as an alloy of $\mathrm{Ni}-\mathrm{Fe}\left(\mathrm{Fe}_{0.64} \mathrm{Ni}_{0.36}\right)$. No $\mathrm{La}_{2} \mathrm{O}_{3}$ diffraction peak was detected in the $\mathrm{Ni}-\mathrm{Fe}-\mathrm{La} / \mathrm{CSC}$ catalyst, which indicated a high dispersion of $\mathrm{La}_{2} \mathrm{O}_{3}$ in the catalyst.

Except for the Ni/CSC catalyst, the active components of the $\mathrm{Ni}-\mathrm{Fe} / \mathrm{CSC}$ and $\mathrm{Ni}$ $\mathrm{Fe}-\mathrm{La} / \mathrm{CSC}$ catalysts had undergone corresponding changes after 10 instances of reuse, and thus affected the catalytic activity of the catalyst. The reasoning might be that the reducing gas, such as $\mathrm{H}_{2}$ and $\mathrm{CO}$, generated during the catalytic gasification of the biomass maintained the active component of the $\mathrm{Ni} / \mathrm{CSC}$ catalyst as $\mathrm{Ni}^{0}$. The active components of the Ni-Fe/CSC catalyst were reduced from $\mathrm{Fe}_{2} \mathrm{O}_{3}$ and $\mathrm{NiO}$ to $\mathrm{Fe}_{3} \mathrm{O}_{4}$ and $\mathrm{Ni}^{0}$, respectively. Moreover, although the active component of the Ni-Fe-La/CSC catalyst was converted from $\mathrm{Fe}_{0.64} \mathrm{Ni}_{0.36}$ to $\mathrm{FeNi}_{3}$ and $\mathrm{Fe}_{3} \mathrm{O}_{4}$, the active component was still mainly nickel-iron alloy.

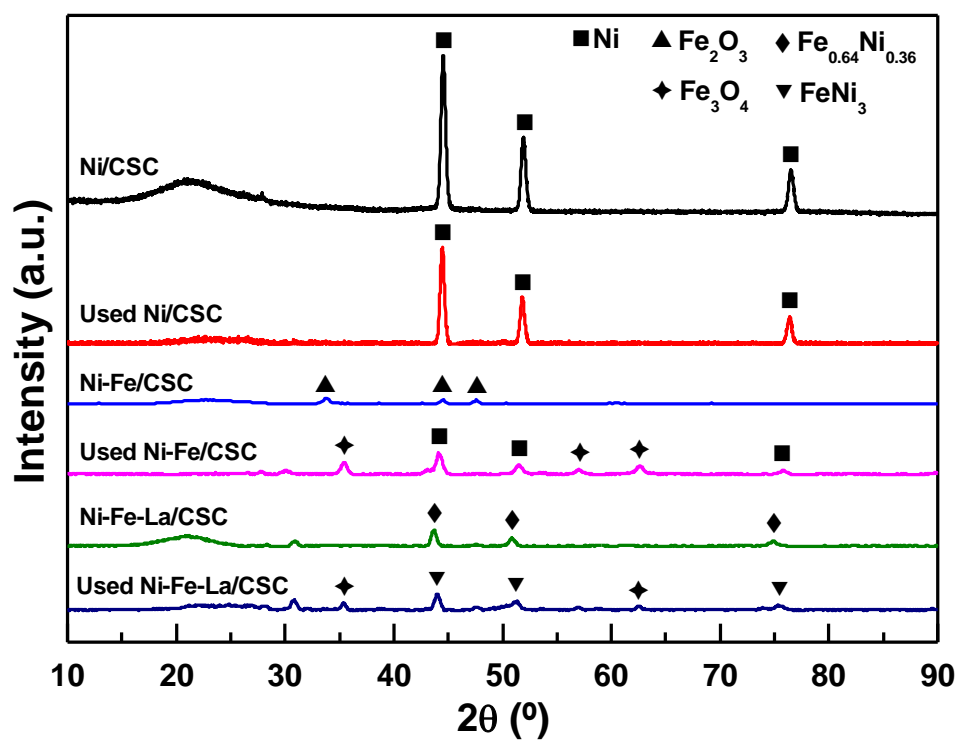

Fig. 3. XRD patterns of char-supported catalysts and used catalysts

\section{XPS analysis}

Figure 4 shows the XPS patterns of Ni/CSC, Ni-Fe/CSC, and Ni-Fe-La/CSC catalysts. The XPS patterns of $\mathrm{C} 1 \mathrm{~s}$ and $\mathrm{Ni} 2 \mathrm{p}$ regions for the $\mathrm{Ni} / \mathrm{CSC}$ catalyst are depicted in Fig. 4(a), with the curve-fitting spectra included. Figure 4(a) shows the binding energy of $\mathrm{C} 1 \mathrm{~s}$ distributed at $284.73 \mathrm{eV}$ in the spectrum. In general, charging effects were corrected by adjusting the binding energy of $\mathrm{C} 1 \mathrm{~s}$ to $284.6 \mathrm{eV}$. Therefore, the binding energy of all elements should be calibrated by subtracting $0.13 \mathrm{eV}$. The Ni $2 \mathrm{p} 3 / 2$ peak of Ni/CSC catalyst at $853.01 \mathrm{eV}$ was the characteristic peak of $\mathrm{Ni}^{0}$, which was in agreement with the results of the XRD analysis. In addition, the $\mathrm{Ni} 2 \mathrm{p} 3 / 2$ peak of $\mathrm{Ni} / \mathrm{CSC}$ catalyst at 855.76 $\mathrm{eV}$ was attributed to the strong interaction with compounds, such as $\mathrm{SiO}_{2}$ and $\mathrm{Fe}_{2} \mathrm{O}_{3}$, formed $\mathrm{NiSiO}_{3}$ and $\mathrm{NiFe}_{2} \mathrm{O}_{4}$.

As shown in Fig. 4(b), the peak of $\mathrm{Ni}^{0}$ disappeared in the spectrum of the Ni$\mathrm{Fe} / \mathrm{CSC}$ catalyst, which indicated that there was no $\mathrm{Ni}^{0}$ present in the $\mathrm{Ni}-\mathrm{Fe} / \mathrm{CSC}$ catalyst. 
This conclusion was also confirmed by the fact that no peak of nickel was observed in the XRD pattern. The binding energy of $\mathrm{Ni} 2 \mathrm{p} 3 / 2$ at $855.93 \mathrm{eV}$ was identified as the peak of $\mathrm{NiFe}_{2} \mathrm{O}_{4}, \mathrm{Ni}(\mathrm{OH})_{2}$, and $\mathrm{Ni}_{2} \mathrm{O}_{3}$. Furthermore, the binding energy of Fe $2 \mathrm{p} 3 / 2$ at $711.69 \mathrm{eV}$ was identified as the peak of $\mathrm{Fe}_{2} \mathrm{O}_{3}$ and $\mathrm{FeO}(\mathrm{OH})$. The Fe 2p3/2 peak had associated satellite peaks.
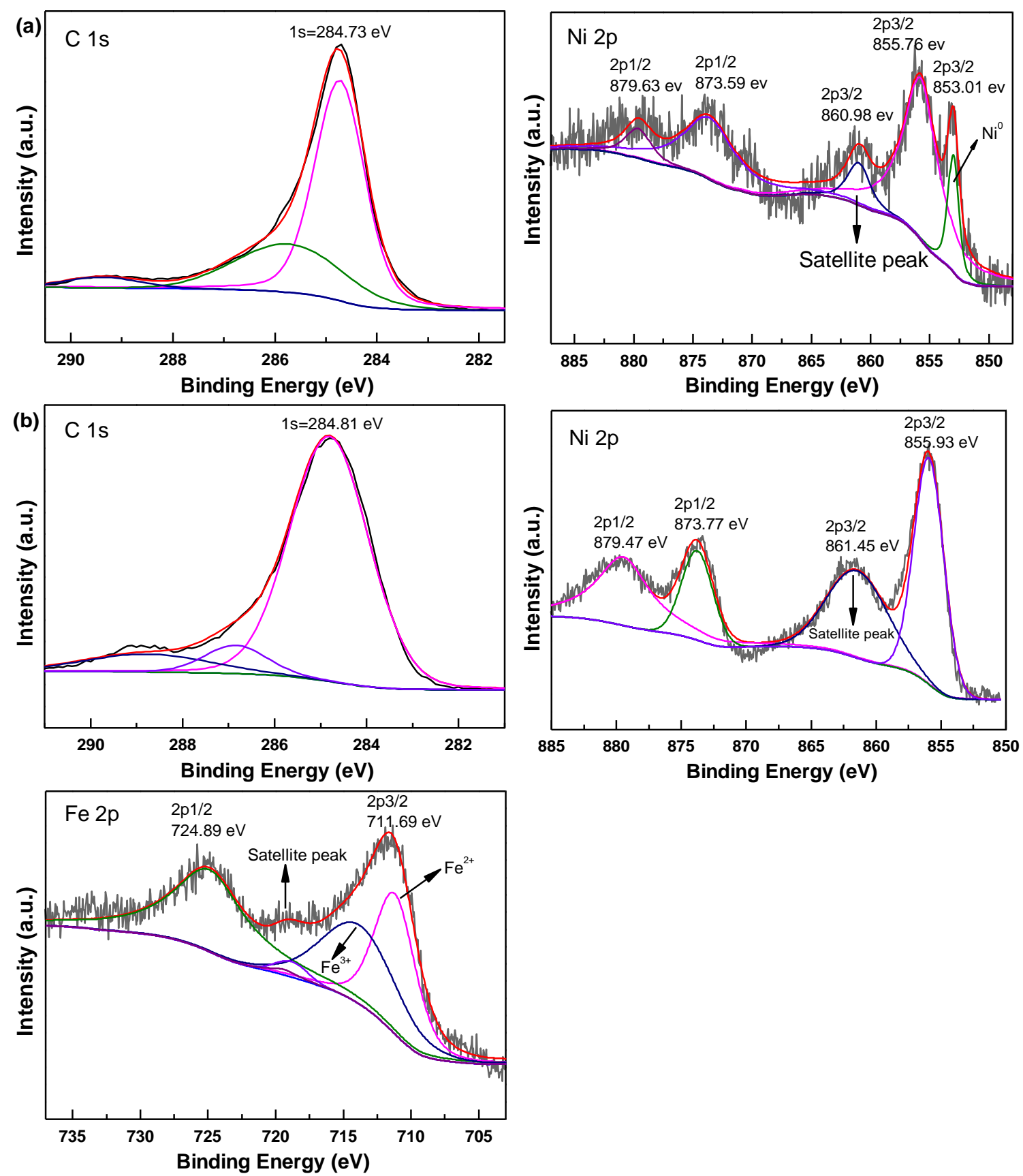

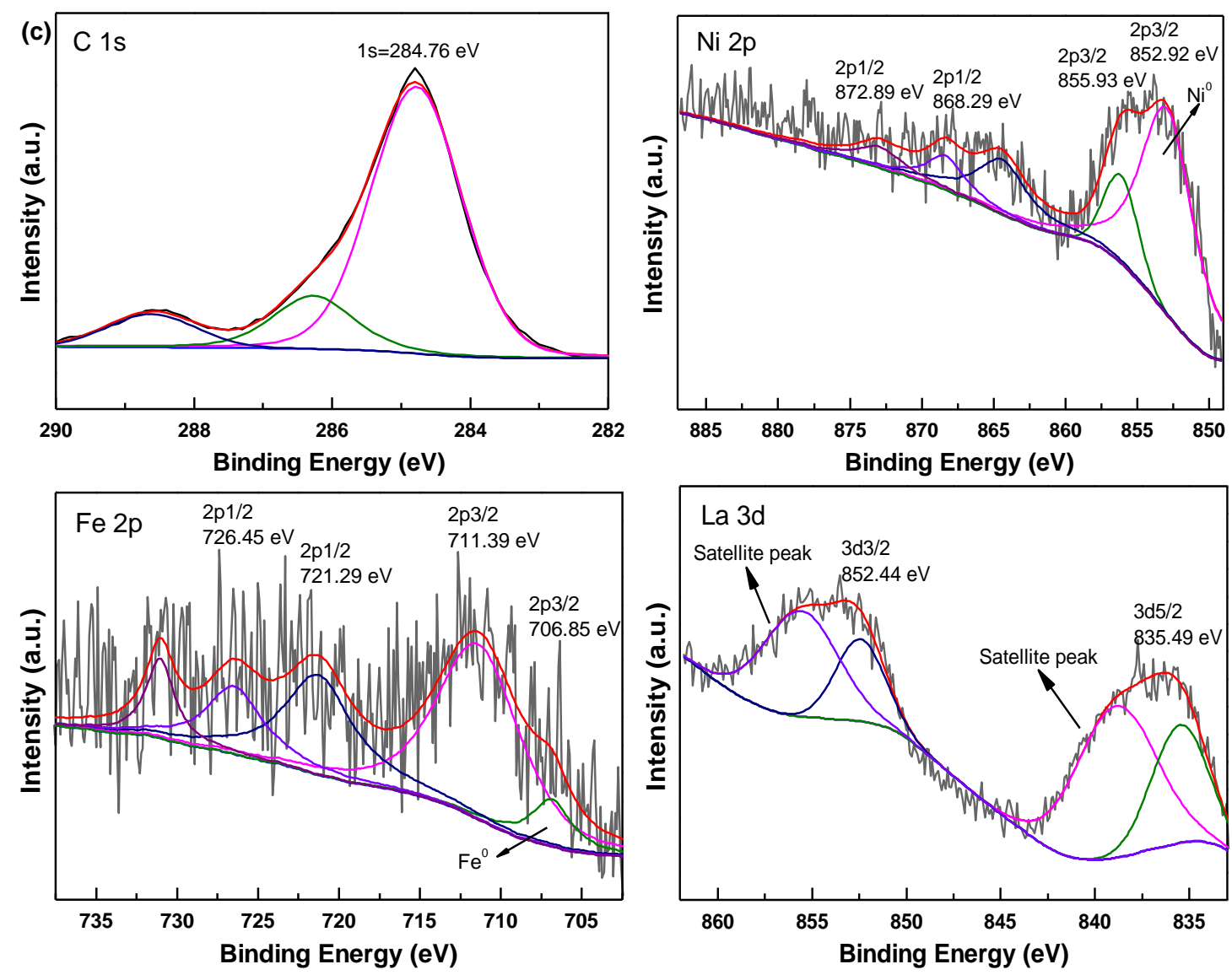

Fig. 4. XPS patterns of char-supported catalysts: (a) Ni/CSC catalyst, (b) Ni-Fe/CSC catalyst, and (c) Ni-Fe-La/CSC catalyst

The satellite peak of $\mathrm{Fe} 2 \mathrm{p} 3 / 2$ for $\mathrm{Fe}_{2} \mathrm{O}_{3}$ was located approximately $8 \mathrm{eV}$ higher than the main Fe 2p3/2 peak (Yamashita and Hayes 2008), which was clearly shown in the spectrum. In the XRD spectrum, the weak peak of $\mathrm{Fe}_{2} \mathrm{O}_{3}$ was also observed. The binding energies at $709.89 \mathrm{eV}$ and $714.33 \mathrm{eV}$ were identified as the peaks of $\mathrm{Fe}^{2+}$ and $\mathrm{Fe}^{3+}(\mathrm{He}$ et al. 2018). Additionally, the Fe $2 \mathrm{p} 3 / 2$ signal showed that the binding energy of the divalent oxide state of $\mathrm{Fe}$ at $709.89 \mathrm{eV}$ was the main signal recorded. The peak at $714.33 \mathrm{eV}$ corresponded to the trivalent-oxide state of Fe. The other peaks correspond to satellites of $\mathrm{Fe}^{2+}$ and $\mathrm{Fe}^{3+}$. Therefore, $\mathrm{FeO}$ was contained in the Ni-Fe/CSC catalyst.

As shown in Fig. 4(c), the binding energies of $\mathrm{Ni} 2 \mathrm{p} 3 / 2$ at $852.92 \mathrm{eV}$ and Fe 2p3/2 at $706.85 \mathrm{eV}$ were identified as the peaks of $\mathrm{Ni}^{0}$ and $\mathrm{Fe}^{0}$, respectively. According to the XRD pattern of the $\mathrm{Ni}-\mathrm{Fe}-\mathrm{La} / \mathrm{CSC}$ catalyst, the alloy of $\mathrm{Ni}-\mathrm{Fe}\left(\mathrm{Fe}_{0.64} \mathrm{Ni}_{0.36}\right)$ was formed in the catalyst. Consequently, the characteristic peaks of $\mathrm{Ni}^{0}$ and $\mathrm{Fe}^{0}$ were observed in the XPS patterns, which also indicated the presence of Ni-Fe alloy. The XPS pattern of the La $3 \mathrm{~d}$ region showed that the deconvolution of the $\mathrm{La} 3 \mathrm{~d}$ spectrum with four lines corresponded to spin-orbit splitting ( $\mathrm{La} \mathrm{3d} 3 / 2$ and $\mathrm{La} \mathrm{3d5/2}$ ) and their shake-up satellites at higher binding energy sites (Sienkiewicz-Gromiuk et al. 2016). The binding energy of $\mathrm{La} 3 \mathrm{~d} 5 / 2$ at $835.49 \mathrm{eV}$ was identified as the peak of $\mathrm{La}_{2} \mathrm{O}_{3}$. Mazumder and De Lasa (2014) showed that $\mathrm{La}_{2} \mathrm{O}_{3}$ could increase the reducible nickel by reducing the formation of $\mathrm{NiAl}_{2} \mathrm{O}_{4}$ spinel, and increase the dispersibility of nickel by reducing the interaction between the metal and the support. In the Ni-Fe-La/CSC catalyst, the presence of $\mathrm{La}_{2} \mathrm{O}_{3}$ 
could increase the dispersibility of the metal and the active site of the catalyst, thus affecting the catalytic performance of the catalyst.

\section{SEM analysis}

Taking the Ni-Fe-La/CSC catalyst as an example, Fig. 5 shows the SEM images of CSC, Ni-Fe-La/CSC catalyst, and used Ni-Fe-La/CSC catalyst. Figure 5(a) shows that the corn stalk became a highly porous carbonaceous material after high temperature pyrolysis. The char support had high adsorption performance due to its uniform structure and developed pores, which resulted in the good residence time of tar reacting with the catalyst. The char support could effectively adsorb tar and crack it on the metal surface, which then increased the content of $\mathrm{H}_{2}$ in the product gas. Figure 5(b) shows that there were some small particles on the surface of the support. Therefore, it can be speculated that the metal had been successfully supported on the surface, and the pore structure was still clean and visible. However, Fig. 5(c) shows that the particles on the surface of the support became larger than before use, which indicated that the use of the catalyst at high temperature for a long time made the metal agglomerate. According to Scherrer formula, the average size of nickel iron alloy grains in the Ni-Fe-La/CSC catalyst increased from $15 \mathrm{~nm}$ to $17 \mathrm{~nm}$ after 10 instances of reuse. Additionally, the pore structure of the support was also unclear, which was attributed to the carbon deposition of the catalyst blocking the void.

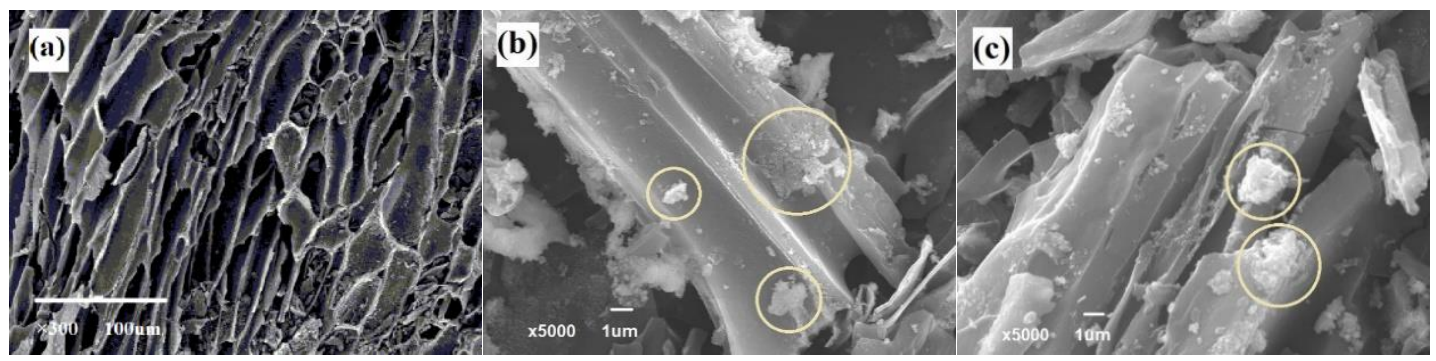

Fig. 5. SEM images of (a) CSC, (b) Ni-Fe-La/CSC catalyst, and (c) used Ni-Fe-La/CSC catalyst

\section{BET analysis}

The textural parameters of CSC, catalysts, and used catalysts, including BET surface area, total pore volume, and average pore diameter, are listed in Table 3. The data show that BET surface area of Ni-Fe/CSC $\left(197.25 \mathrm{~m}^{2} / \mathrm{g}\right)$ was the highest among these three catalysts, and that BET surface area of Ni/CSC was the smallest $\left(16.49 \mathrm{~m}^{2} / \mathrm{g}\right)$. It might have been attributed to the worst thermal stability of Ni-Fe/CSC catalyst, which resulted in a larger specific surface area during catalyst preparation.

Table 3. Textural Parameters of CSC, Catalysts, and Used Catalysts

\begin{tabular}{|c|c|c|c|}
\hline Sample & $\begin{array}{c}\text { BET Surface Area } \\
\left(\mathrm{m}^{2} / \mathrm{g}\right)\end{array}$ & $\begin{array}{c}\text { Total Pore Volume } \\
\left(\mathrm{cm}^{3} / \mathrm{g}\right)\end{array}$ & $\begin{array}{c}\text { Average Pore } \\
\text { Diameter }(\mathrm{nm})\end{array}$ \\
\hline $\mathrm{CSC}$ & 16.27 & 0.030 & 53.36 \\
\hline $\mathrm{Ni} / \mathrm{CSC}$ & 16.49 & 0.035 & 49.14 \\
\hline Used Ni/CSC & 2.62 & 0.011 & 127.21 \\
\hline $\mathrm{Ni}-\mathrm{Fe} / \mathrm{CSC}$ & 197.25 & 0.246 & 26.15 \\
\hline Used Ni-Fe/CSC & 9.79 & 0.037 & 69.74 \\
\hline $\mathrm{Ni}-\mathrm{Fe}-\mathrm{La} / \mathrm{CSC}$ & 73.69 & 0.130 & 43.57 \\
\hline Used Ni-Fe-La/CSC & 5.70 & 0.050 & 150.78 \\
\hline
\end{tabular}


Furthermore, it was found that the BET surface area and pore volume of the catalyst decreased after 10 instances of reuse. Carbon deposition of the catalyst would block some micropores, which would result in a decrease in the BET surface area. Compared with the fresh catalysts, the used catalysts had a larger pore diameter due to the constant consumption of the char-supported catalyst during reuse. In addition, all three catalysts had a mesoporous structure, which also indicated that they had strong performances for adsorption.

\section{FTIR analysis}

Figure 6 shows the FTIR spectra of CSC, Ni/CSC, Ni-Fe/CSC, and Ni-Fe-La/CSC catalysts. A large number of studies have shown that biochar can adsorb tar produced during biomass gasification (Paethanom et al. 2012, 2013). The mechanism of tar adsorption by biochar is complex, which is related not only to the pore structure of biochar, but also to the functional groups on the surface of biochar. There was a strong and wide absorption band between $3250 \mathrm{~cm}^{-1}$ and $3750 \mathrm{~cm}^{-1}$, which was identified as $-\mathrm{OH}$ stretching vibrations. The peak at $3200 \mathrm{~cm}^{-1}$ was likely indicative of $-\mathrm{NH}_{2}$ stretching vibrations. Additionally, $-\mathrm{NH}_{2}$ was a basic functional group, while phenol was a Lewis acid. Therefore, phenol can easily combine with $-\mathrm{NH}_{2}$ via the acid-base interaction (Shen et al. 2016), and thereby be adsorbed by biochar. Then, it will undergo catalytic cracking reaction at the active site on the char-supported catalyst. The peaks at $1100 \mathrm{~cm}^{-1}$ and 1700 $\mathrm{cm}^{-1}$ were likely indicative of $\mathrm{C}-\mathrm{O}$ and $\mathrm{C}=\mathrm{O}$ stretching vibrations, respectively. Some organic functional groups, such as $-\mathrm{OH}, \mathrm{C}-\mathrm{O}$, and $\mathrm{C}=\mathrm{O}$, can interact with phenol via hydrogen bonds. Moreover, the chemical interaction between the functional group and the phenol molecule can effectively enhance the adsorption (Liu et al. 2011).

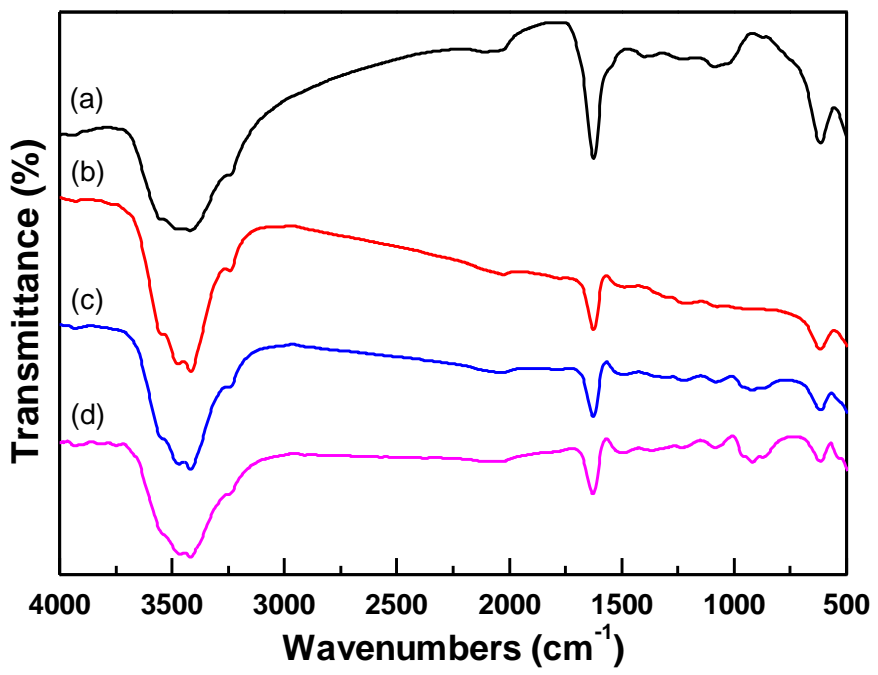

Fig. 6. FTIR spectra of CSC and char-support catalysts: (a) CSC, (b) Ni/CSC, (c) Ni-Fe/CSC, and (d) Ni-Fe-La/CSC

\section{Catalytic Performance of $\mathrm{Ni} / \mathrm{CSC}, \mathrm{Ni}-\mathrm{Fe} / \mathrm{CSC}$, and Ni-Fe-La/CSC Catalysts}

Reactor temperature, catalyst type, moisture content of wet sludge, and catalyst recycling performance were explored in this experiment. The catalytic activity of catalysts in biomass gasification was evaluated through comparing $\mathrm{H}_{2}$ and $\mathrm{CO}$ content in the product gas. The important reactions taking place during catalytic gasification of wet sludge and straw are summarized as follows (Yang et al. 2018): 
Drying process: Wet sample $\rightarrow$ steam + dry sample

Pyrolysis: Dry sample $\rightarrow$ gas + tar + char

Secondary cracking: Tar $\rightarrow \mathrm{H}_{2}+\mathrm{CO}+\mathrm{CO}_{2}+\mathrm{CH}_{4}+\mathrm{H}_{2} \mathrm{O}+\mathrm{C}_{\mathrm{n}} \mathrm{H}_{\mathrm{m}}$

Steam gasification reaction: $\mathrm{C}_{\mathrm{n}} \mathrm{H}_{\mathrm{m}}+\mathrm{nH}_{2} \mathrm{O}+\mathrm{Q} \rightarrow \mathrm{nCO}+[\mathrm{n}+(\mathrm{m} / 2)] \mathrm{H}_{2}$

Methane reforming reaction: $\mathrm{CH}_{4}+\mathrm{H}_{2} \mathrm{O} \rightarrow \mathrm{CO}+3 \mathrm{H}_{2}+206 \mathrm{~kJ} / \mathrm{mol}$

Water gas shift reaction: $\mathrm{CO}+\mathrm{H}_{2} \mathrm{O} \rightarrow \mathrm{CO}_{2}+\mathrm{H}_{2}-41 \mathrm{~kJ} / \mathrm{mol}$

Char steam gasification reaction: $\mathrm{C}+\mathrm{H}_{2} \mathrm{O} \rightarrow \mathrm{CO}+\mathrm{H}_{2}+131 \mathrm{~kJ} / \mathrm{mol}$

Boudouard reaction: $\mathrm{C}+\mathrm{CO}_{2} \rightarrow 2 \mathrm{CO}+172 \mathrm{~kJ} / \mathrm{mol}$

Figure 7 shows the processes of biomass catalytic gasification and catalyst preparation. First, what happened to the wet sample at high temperature was the drying process, which formed in-situ steam around the sample (Eq. 2). Meanwhile, the dry sample was rapidly pyrolyzed to gas, tar, and char (Eq. 3), followed by secondary cracking of tar to form gas and small molecule organic matter (Eq. 4), steam gasification reaction, methane reforming reaction, water gas shift reaction, char steam gasification reaction, and Boudouard reaction (Eqs. 5 through 9). The primary gas was produced from the thermal scission of chemical bonds in the individual constituents of biomass, when catalytic reforming reactions cleaved the $\mathrm{C}-\mathrm{C}$ and $\mathrm{C}-\mathrm{H}$ bonds of the carbohydrate backbone to produce $\mathrm{CO}$ and $\mathrm{H}_{2}$ (Kunkes et al. 2008). Due to the presence of in-situ steam, char steam gasification reaction could not only refresh the active surface area of catalyst by reducing the carbon deposit of the catalyst, but also increase the $\mathrm{CO}$ and $\mathrm{H}_{2}$ content in the gas.

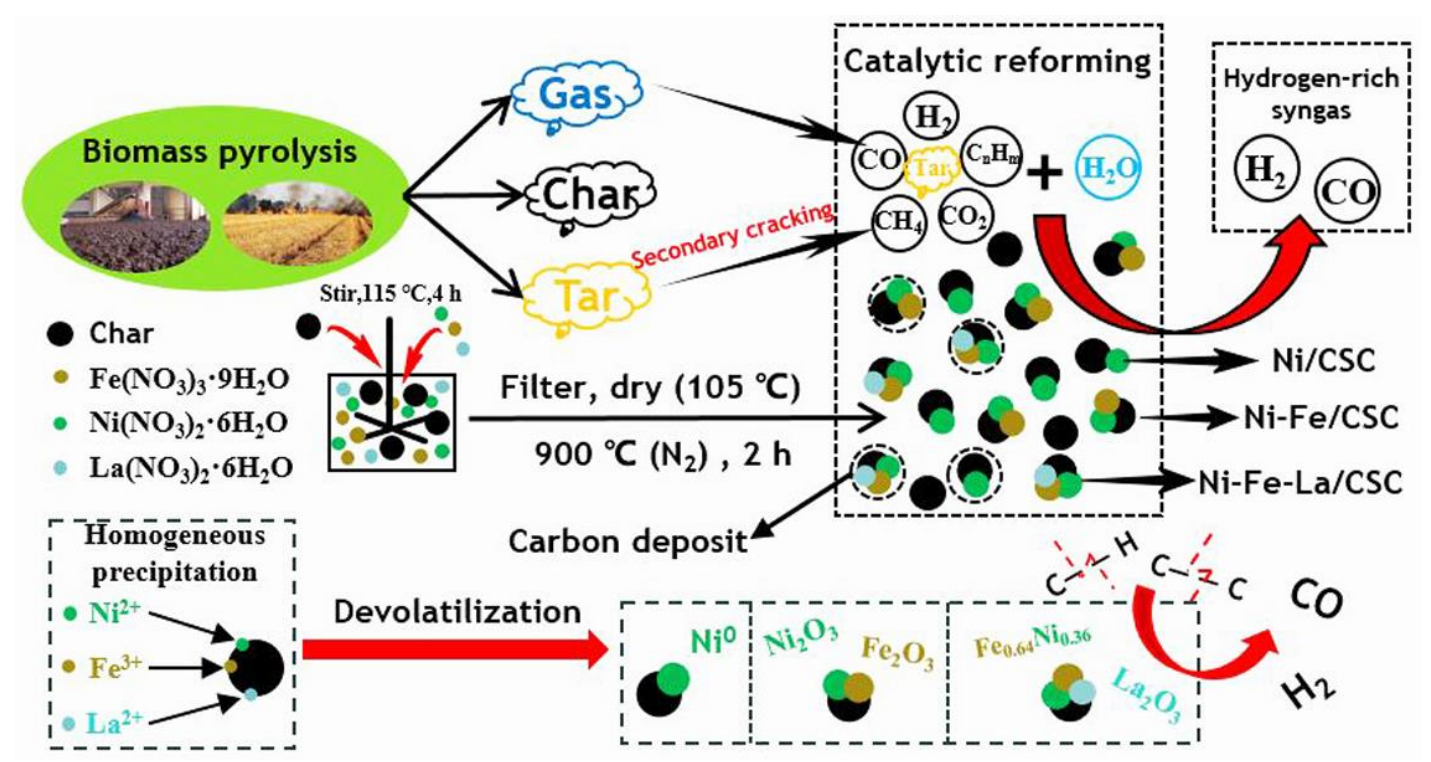

Fig. 7. Processes of catalytic gasification of biomass using Ni/CSC, Ni-Fe/CSC, and Ni-Fe$\mathrm{La} / \mathrm{CSC}$ catalysts 


\section{Influence of reactor temperature on gas composition}

The reactor temperature played an important role in the co-gasification of wet sludge and straw, because the decomposition temperatures of various components, such as hemicellulose, cellulose, lignin, aliphatic compounds, and proteins, were different, and the process was an endothermic reaction. It could be seen from Fig. 8 that the trends of gas composition change were almost the same regardless of the catalyst. The contents of $\mathrm{H}_{2}$ and $\mathrm{CO}$ increased gradually with the increase of reactor temperature while the contents of $\mathrm{CH}_{4}$ and $\mathrm{CO}_{2}$ decreased. Yang et al. (2018) have studied the co-gasification of wet sludge and sawdust and found the same trend, which was attributed to higher temperature providing more favorable conditions for thermal cracking of hydrocarbon. Taking Fig. 8(c) as an example, the content of $\mathrm{H}_{2}$ increased from $32.03 \mathrm{vol} \%$ to $46.89 \mathrm{vol} \%$, a $46.39 \%$ relative increase. At the same time, the CO content increased from 26.32 vol\% to 34.34 vol\%, a $30.47 \%$ relative increase. The main reason for this phenomenon was that the cracking of cycloalkanes and the breaking of the long chains of macromolecules would be gradually increased with the increase of reactor temperature. Additionally, according to Le Chatelier's principle, higher temperature was favorable for increasing products in the endothermic reactions and reactants in the exothermic reactions. In other words, raising the reactor temperature promoted the steam gasification reaction of hydrocarbon, methane reforming reaction, char steam gasification reaction, and Boudouard reaction. Moreover, the water gas shift reaction was suppressed. Thereby, a large number of hydrocarbons, $\mathrm{CO}_{2}$, and $\mathrm{CH}_{4}$ were consumed and converted into $\mathrm{H}_{2}$ and $\mathrm{CO}$, and $\mathrm{CO}$ was prevented from being converted to $\mathrm{CO}_{2}$.
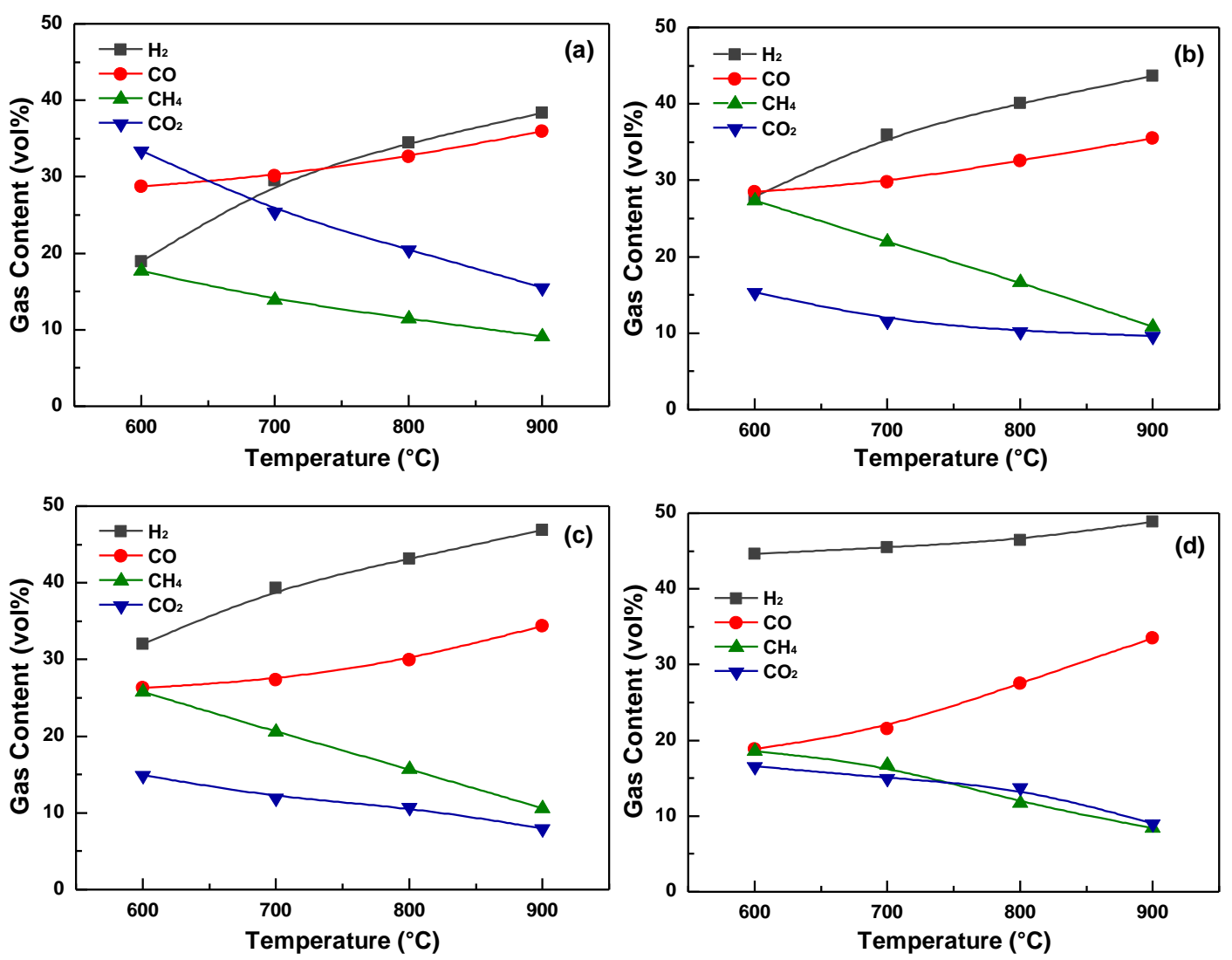

Fig. 8. Influence of reactor temperature on gas composition: (a) No catalyst, (b) Ni/CSC, (c) Ni$\mathrm{Fe} / \mathrm{CSC}$, and (d) Ni-Fe-La/CSC 


\section{Influence of the catalyst on syngas}

As shown in Fig. 9, compared with the dry sample, the wet sample could form insitu steam during gasification to increase the $\mathrm{H}_{2}$ content in the gas phase. With higher reactor temperatures, the effect was more noticeable, which could be explained by the process from Eqs. 5 through 9. In addition, in the absence of the catalyst, the $\mathrm{CO}$ content was higher than that of $\mathrm{H}_{2}$. However, the content of $\mathrm{H}_{2}$ was remarkably higher than that of $\mathrm{CO}$ when the catalyst was used. This indicated that the catalysts played a crucial role in the process of biomass gasification that was prepared hydrogen-rich syngas.
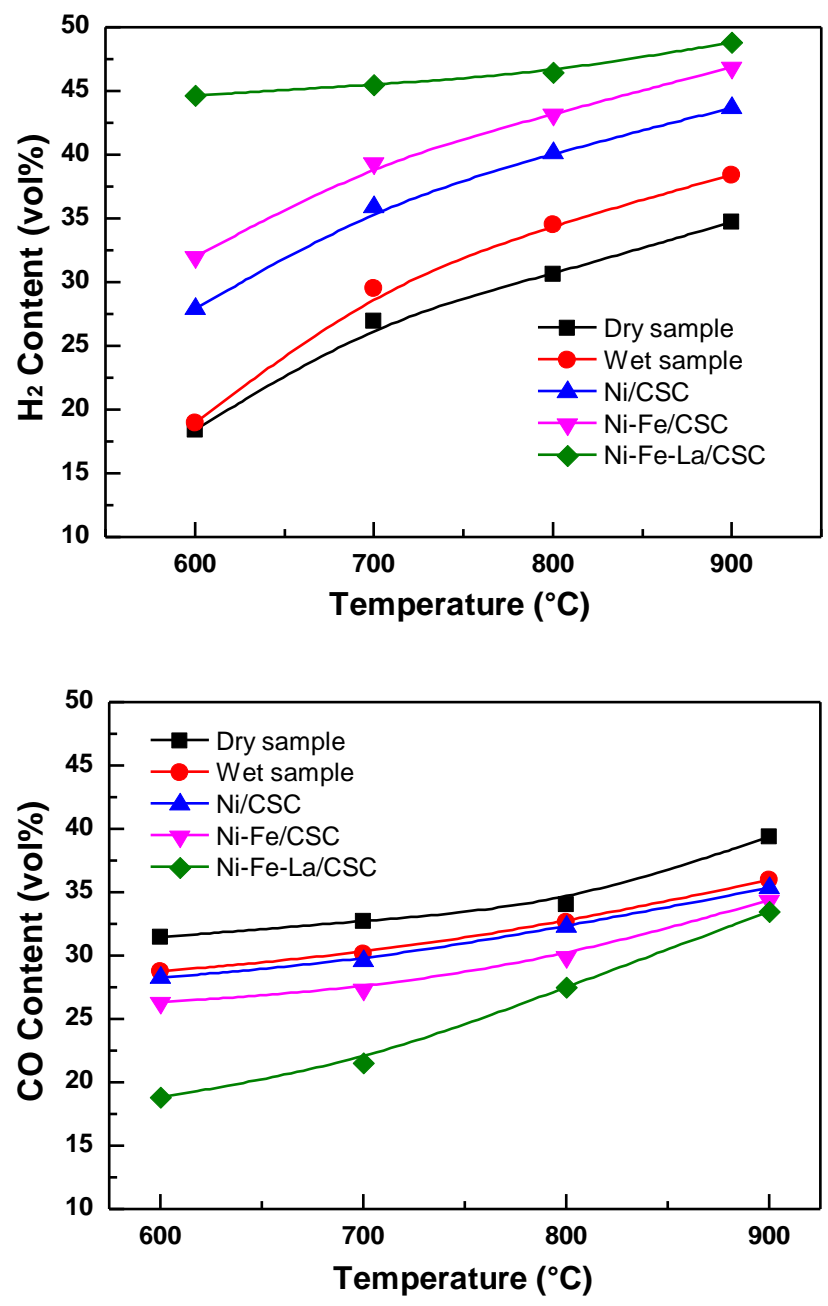

Fig. 9. Influence of the catalyst on syngas

Table 4 shows gas composition, dry gas yield, $\mathrm{H}_{2}$ yield, and LHV from catalytic insitu steam gasification of biomass with different catalysts. It shows that the dry gas yield, $\mathrm{H}_{2}$ yield, and $\mathrm{LHV}$ at $600{ }^{\circ} \mathrm{C}$ in-situ steam gasification in the absence of catalyst were 0.45 $\mathrm{N} \cdot \mathrm{m}^{3} / \mathrm{kg}, 3.80 \mathrm{~mol} / \mathrm{kg}$, and $18.56 \mathrm{MJ} / \mathrm{N}^{\circ} \mathrm{m}^{3}$, respectively. The Ni-Fe-La/CSC catalyst showed the highest catalytic activity for dry gas yield $\left(0.60 \mathrm{~N} \cdot \mathrm{m}^{3} / \mathrm{kg}\right)$ and $\mathrm{H}_{2}$ yield $(11.96$ $\mathrm{mol} / \mathrm{kg}$ ) compared with the Ni/CSC and Ni-Fe/CSC catalysts. However, the LHV (15.03 $\mathrm{MJ} / \mathrm{N} \cdot \mathrm{m}^{3}$ ) of gas was the lowest, which resulted from the fact that $\mathrm{CH}_{4}$ and $\mathrm{C}_{n} \mathrm{H}_{\mathrm{m}}$ had much higher calorific values than $\mathrm{H}_{2}$ or $\mathrm{CO}$. As shown in Fig. 9, regardless of the reactor temperature, Ni-Fe-La/CSC catalyst showed the best catalytic effect due to the presence of 
nickel-iron alloy $\left(\mathrm{Fe}_{0.64} \mathrm{Ni}_{0.36}\right)$. Xie et al. (2018) prepared nanofiber-supported $\mathrm{Fe}-\mathrm{Ni}$ bimetallic catalysts for biomass gasification. The results showed that the $\mathrm{Fe}_{0.64} \mathrm{Ni}_{0.36}$ alloy detected in the Fe-Ni/carbon nanofibers catalyst had a remarkably high catalytic ability to aromatic compounds. Moreover, the catalytic effect of the Ni-Fe/CSC catalyst was better than that of the Ni/CSC catalyst because the oxide of iron in the Ni-Fe/CSC catalyst contributed to the generation of $\mathrm{H}_{2}$ and the gasification reaction (Shen et al. 2014). The catalytic effect of Ni-Fe-La/CSC catalyst was not noticeably improved at high temperature compared with $\mathrm{Ni} / \mathrm{CSC}$ and $\mathrm{Ni}-\mathrm{Fe} / \mathrm{CSC}$ catalysts, but the catalytic effect of $\mathrm{Ni}-\mathrm{Fe}-\mathrm{La} / \mathrm{CSC}$ catalyst was remarkably improved at low temperature. For example, compared with the case without catalyst, when the temperature was $600{ }^{\circ} \mathrm{C}$, the $\mathrm{H}_{2}$ content after using Ni-Fe$\mathrm{La} / \mathrm{CSC}$ catalyst increased from 18.93 vol\% to $44.65 \mathrm{vol} \%$, a $135.87 \%$ relative increase. However, when the temperature was $900{ }^{\circ} \mathrm{C}$, the content of $\mathrm{H}_{2}$ increased from $38.41 \mathrm{vol} \%$ to $48.84 \mathrm{vol} \%$, a $27.15 \%$ relative increase. At the same time, with the increase of temperature, for the $\mathrm{Ni}-\mathrm{Fe}-\mathrm{La} / \mathrm{CSC}$ catalyst, the tendency of $\mathrm{H}_{2}$ content to increase was relatively flat. According to Fig. 5, it could be speculated that the metal was agglomerated at high temperature, which affected the active surface area of the catalyst. In conclusion, the newly developed Ni-Fe-La/CSC catalyst showed high application value in the production of valuable gas in biomass cryogenic gasification. When the catalytic temperature was $600{ }^{\circ} \mathrm{C}$, the $\mathrm{H}_{2}$ yield reached $11.96 \mathrm{~mol} / \mathrm{kg}$.

Table 4. Influence of Catalyst on Gas Composition and Gas Characterization

\begin{tabular}{|c|c|c|c|c|}
\hline Catalyst & No Catalyst & $\mathrm{Ni} / \mathrm{CSC}$ & $\mathrm{Ni}-\mathrm{Fe} / \mathrm{CSC}$ & $\mathrm{Ni}-\mathrm{Fe}-\mathrm{La} / \mathrm{CSC}$ \\
\hline Gasification Temperature $\left({ }^{\circ} \mathrm{C}\right)$ & 600 & 600 & 600 & 600 \\
\hline Catalytic Temperature $\left({ }^{\circ} \mathrm{C}\right)$ & 600 & 600 & 600 & 600 \\
\hline $\mathrm{H}_{2}$ Content $(\mathrm{vol} \%)$ & 18.93 & 27.89 & 32.03 & 44.65 \\
\hline $\mathrm{CO}$ Content $(\mathrm{vol} \%)$ & 28.72 & 28.45 & 26.32 & 18.84 \\
\hline $\mathrm{CH}_{4}$ Content $(\mathrm{vol} \%)$ & 33.39 & 27.34 & 25.80 & 18.61 \\
\hline $\mathrm{CO}_{2}$ Content $(\mathrm{vol} \%)$ & 17.73 & 15.37 & 14.89 & 16.62 \\
\hline $\mathrm{C}_{n} \mathrm{H}_{\mathrm{m}}$ Content $(\mathrm{vol} \%)$ & 1.23 & 0.95 & 0.95 & 1.29 \\
\hline Dry Gas Yield $\left(\mathrm{N} \cdot \mathrm{m}^{3} / \mathrm{kg}\right)$ & 0.45 & 0.53 & 0.56 & 0.60 \\
\hline $\mathrm{H}$ Yield $(\mathrm{mol} / \mathrm{kg})$ & 3.80 & 6.60 & 8.01 & 11.96 \\
\hline $\mathrm{LHV}\left(\mathrm{MJ} / \mathrm{N} \cdot \mathrm{m}^{3}\right)$ & 18.56 & 17.22 & 16.87 & 15.03 \\
\hline
\end{tabular}

Influence of moisture content of wet sludge on syngas

The wet sludge (the dry sludge was $1 \mathrm{~g}$ ) with moisture contents of $30 \mathrm{wt} \%$, $40 \mathrm{wt} \%$, $50 \mathrm{wt} \%, 60 \mathrm{wt} \%, 70 \mathrm{wt} \%$, and $80 \mathrm{wt} \%$ were separately blended uniformly with $1 \mathrm{~g}$ straw, and the moisture content of the blended biomass samples were $17.7 \mathrm{wt} \%, 25.1 \mathrm{wt} \%, 33.3$ $\mathrm{wt} \%, 42.86 \mathrm{wt} \%, 53.81 \mathrm{wt} \%$, and $66.67 \mathrm{wt} \%$, respectively. Then, the samples were gasified at $600{ }^{\circ} \mathrm{C}$ using the $\mathrm{Ni}-\mathrm{Fe}-\mathrm{La} / \mathrm{CSC}$ catalyst. Figure 10 shows the influence of moisture content of wet sludge on syngas and $\mathrm{H}_{2}$ yield.

It was shown that the $\mathrm{H}_{2}$ content and $\mathrm{H}_{2}$ yield showed a trend of first increasing and then decreasing as the moisture content of wet sludge increased. As the moisture content of wet sludge increased from $30 \mathrm{wt} \%$ to $60 \mathrm{wt} \%$, the $\mathrm{H}_{2}$ content gradually increased from $38.81 \mathrm{vol} \%$ to $44.65 \mathrm{vol} \%$, and the $\mathrm{H}_{2}$ yield increased from $9.44 \mathrm{~mol} / \mathrm{kg}$ to $11.96 \mathrm{~mol} / \mathrm{kg}$. When the moisture content was further increased from $60 \mathrm{wt} \%$ to $80 \mathrm{wt} \%$, the $\mathrm{H}_{2}$ content declined from a maximum value of 44.65 vol\% to 38.27 vol\%, and the $\mathrm{H}_{2}$ yield decreased from $11.96 \mathrm{~mol} / \mathrm{kg}$ to $11.10 \mathrm{~mol} / \mathrm{kg}$. The variations emerged because in-situ steam was used as a gasifying agent, which could promote steam gasification, methane reforming, water gas shift, and char steam gasification reactions (Eqs. 5 through 8) and thereby 
increase the content of $\mathrm{H}_{2}$. However, with the increase of moisture content of wet sludge, more heat would be needed for endothermic reaction. What's more, excess steam would consume more energy and limit heat transfer between the heating furnace and the biomass, which might make gasification temperature lower than theoretical temperature. In addition, the $\mathrm{CO}$ content gradually decreased with the increase of moisture content of wet sludge. The possible reason was that the increasing steam concentration promoted the water gas shift reaction (Eq. 7) to consume CO. In conclusion, when the moisture content of the mixed biomass was approximately $40 \mathrm{wt} \%$, both the $\mathrm{H}_{2}$ content $\left(44.65 \mathrm{vol} \%\right.$ ) and $\mathrm{H}_{2}$ yield $(11.96 \mathrm{~mol} / \mathrm{kg})$ reached the maximum.

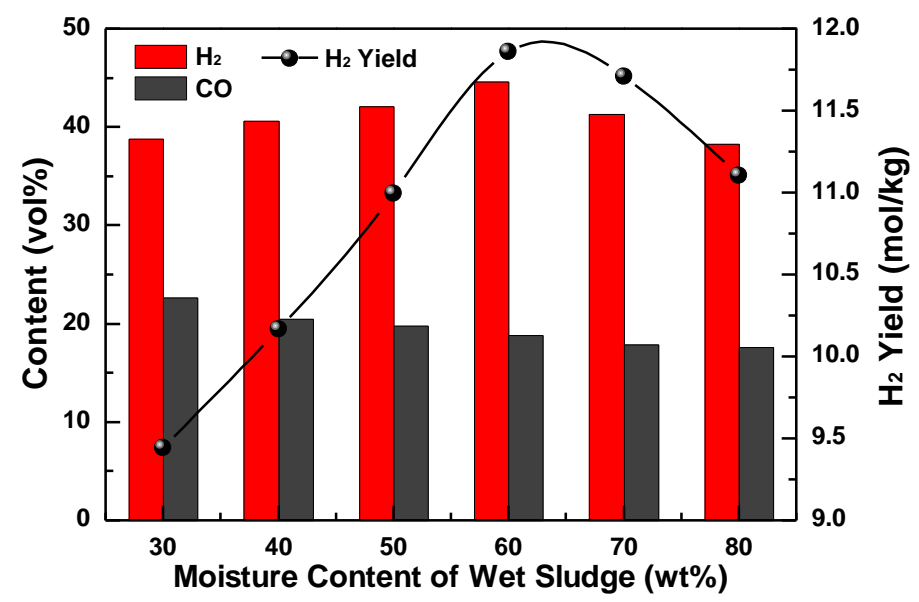

Fig. 10. Influence of moisture content of wet sludge on syngas and $\mathrm{H}_{2}$ yield

\section{Catalyst cyclability}

The testing results of the 10-cycling that used Ni/CSC, Ni-Fe/CSC, and Ni-Fe$\mathrm{La} / \mathrm{CSC}$ catalysts are shown in Fig. 11. The figure shows that the catalytic performance of the catalyst and the $\mathrm{H}_{2}$ content tended to decrease with the increase of cycle test times. Additionally, the catalytic effects of Ni-Fe/CSC and Ni-Fe-La/CSC catalyst tended to be stable after 8 and 4 instances of reuse, while the catalytic effect of the Ni/CSC catalyst kept declining. After 10 instances of reuse, the $\mathrm{H}_{2}$ content decreased by $5.29 \%, 9.51 \%$, and $11.77 \%$, respectively, which indicated that the Ni-Fe-La/CSC catalysts exhibited stable catalytic performance. As shown in Table 2, the carbon deposition of the Ni-Fe-La/CSC catalyst was the lowest. Al-Fatesh et al. (2014) showed that $\mathrm{La}_{2} \mathrm{O}_{3}$ could decrease the acidity of the support, thereby stopped pyrolytic carbon formation, and the basic $\mathrm{La}_{2} \mathrm{O}_{3}$ favored the chemisorption and dissociation of $\mathrm{CO}_{2}$ and reverse Boudouard reaction. Therefore, $\mathrm{La}_{2} \mathrm{O}_{3}$ could extend the usage time of $\mathrm{Ni}-\mathrm{Fe}-\mathrm{La} / \mathrm{CSC}$ catalyst by reducing the carbon deposition. Another reason was that the active components of Ni-Fe-La/CSC catalyst had not changed and it was still nickel-iron alloy after reuse. However, the active components of $\mathrm{Ni}-\mathrm{Fe} / \mathrm{CSC}$ catalyst were converted from $\mathrm{Fe}_{2} \mathrm{O}_{3}$ and $\mathrm{NiO}$ to $\mathrm{Fe}_{3} \mathrm{O}_{4}$ and $\mathrm{Ni}^{0}$, respectively, which would consume reducing gases, such as $\mathrm{H}_{2}$ and $\mathrm{CO}$, which resulted in the decrease of $\mathrm{H}_{2}$ content in the product gas. Although the active component of Ni/CSC catalyst was always $\mathrm{Ni}^{0}$, the content of $\mathrm{H}_{2}$ in the gas phase gradually decreased, even lower than that without catalyst after 7 instances of reuse. It could be speculated that the active component of $\mathrm{Ni} / \mathrm{CSC}$ catalyst was not always $\mathrm{Ni}^{0}$ while it was converted between $\mathrm{NiO}$ and $\mathrm{Ni}^{0}$. Once $\mathrm{NiO}$ was produced, it would be reduced to $\mathrm{Ni}^{0}$ by $\mathrm{H}_{2}$ and $\mathrm{CO}$, which resulted in a gradual decrease of $\mathrm{H}_{2}$ content in the gas phase. 


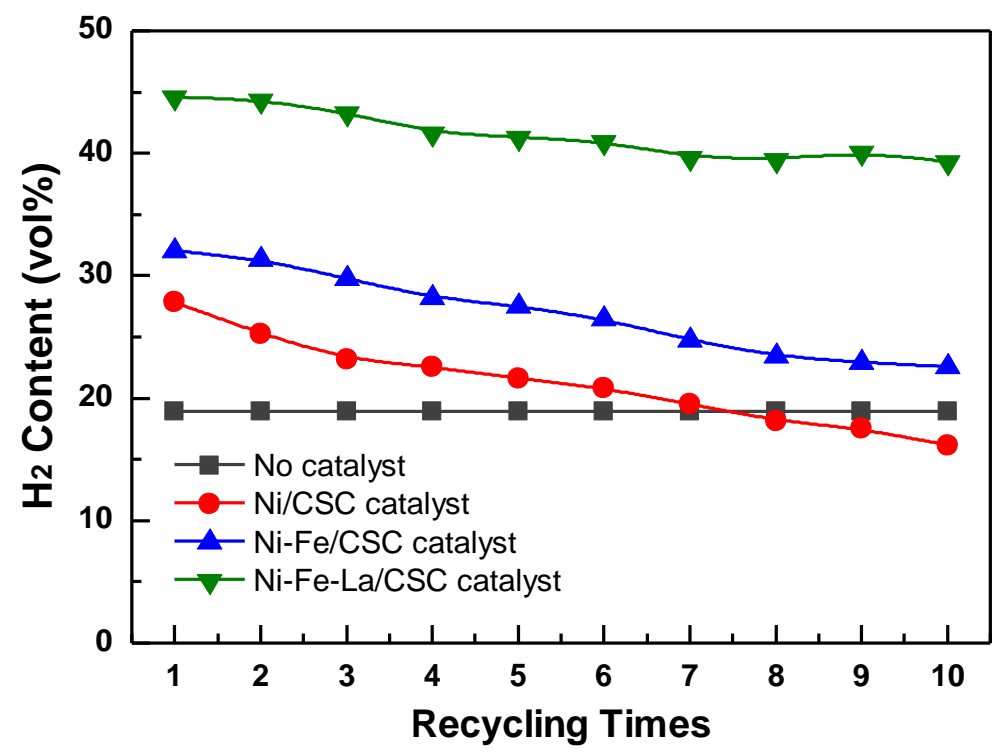

Fig. 11. The $\mathrm{H}_{2}$ content of cycling test with $\mathrm{Ni} / \mathrm{CSC}, \mathrm{Ni}-\mathrm{Fe} / \mathrm{CSC}$, and Ni-Fe-La/CSC catalysts

\section{CONCLUSIONS}

1. After 10 instances of reuse, there was a slight deposition of coke on the surface of catalysts, and the carbon deposition of Ni-Fe-La/CSC catalyst was the least, followed by $\mathrm{Ni}-\mathrm{Fe} / \mathrm{CSC}$ catalyst and $\mathrm{Ni} / \mathrm{CSC}$ catalyst.

2. The Ni/CSC and Ni-Fe-La/CSC catalysts exhibited high thermal stability, but the thermal stability of the Ni-Fe/CSC catalyst and char support were poor. The maximum mass loss of char support reached $40 \mathrm{wt} \%$.

3. Except for the Ni/CSC catalyst, the active components of the $\mathrm{Ni}-\mathrm{Fe} / \mathrm{CSC}$ and $\mathrm{Ni}-\mathrm{Fe}-$ $\mathrm{La} / \mathrm{CSC}$ catalysts had undergone corresponding changes after 10 instances of reuse, and thus affected the catalytic activity of the catalyst.

4. Both char support and char-supported catalysts had abundant mesoporous structure and surface functional groups, and the BET surface area and pore volume of the catalysts decreased after 10 instances of reuse.

5. Long time use of catalyst at high temperature will make the metal agglomerate. The average size of nickel iron alloy grains in the Ni-Fe-La/CSC catalyst increased from 15 $\mathrm{nm}$ to $17 \mathrm{~nm}$ after 10 instances of reuse.

6. Higher temperature could promote the syngas production. With the addition of the $\mathrm{Ni} / \mathrm{CSC}, \mathrm{Ni}-\mathrm{Fe} / \mathrm{CSC}$ and $\mathrm{Ni}-\mathrm{Fe}-\mathrm{La} / \mathrm{CSC}$ catalyst, the $\mathrm{H}_{2}$ yield increased from 3.80 $\mathrm{mol} / \mathrm{kg}$ to $6.60 \mathrm{~mol} / \mathrm{kg}, 8.01 \mathrm{~mol} / \mathrm{kg}$ and $11.96 \mathrm{~mol} / \mathrm{kg}$, respectively.

7. The $\mathrm{H}_{2}$ content and $\mathrm{H}_{2}$ yield showed a trend of first increasing and then decreasing as the moisture content of wet sludge increased. When the moisture content of the mixed biomass was approximately $40 \mathrm{wt} \%$, both the $\mathrm{H}_{2}$ content and $\mathrm{H}_{2}$ yield reached the maximum. 
8. The Ni-Fe-La/CSC catalyst exhibited stable catalytic performance. After 10 instances of reuse, the $\mathrm{H}_{2}$ content only decreased by $5.29 \%$. However, the stable cyclability of $\mathrm{Ni} / \mathrm{CSC}$ and $\mathrm{Ni}-\mathrm{Fe} / \mathrm{CSC}$ catalysts were poor.

\section{ACKNOWLEDGMENTS}

The authors are grateful for the support of the Technology Innovation Major Project of Hubei Province (No. 2017ABA155), the Central Committee Guide Local Science and Technology Development Special Project of Hubei Province (No. 2018ZYYD062), and the Hubei Provincial Natural Science Foundation of China (No. 2018CFB280).

\section{REFERENCES CITED}

Akkache, S., Hernández, A.-B., Teixeira, G., Gelix, F., Roche, N., and Ferrasse, J. H. (2016). "Co-gasification of usedwater sludge and different feedstock: Feasibility study," Biomass Bioenerg. 89, 201-209. DOI: 10.1016/j.biombioe.2016.03.003

Al-Fatesh, A. S., Naeem, M. A., Fakeeha, A. H. and Abasaeed, A. E. (2014). "Role of $\mathrm{La}_{2} \mathrm{O}_{3}$ as promoter and support in $\mathrm{Ni} / \gamma-\mathrm{Al}_{2} \mathrm{O}_{3}$ catalysts for dry reforming of methane," Chin. J. Chem. Eng. 221, 28-37. DOI: 10.1016/S1004-9541(14)60029-X.

Al-Rahbi, A. S., and Williams, P. T. (2017). "Hydrogen-rich syngas production and tar removal from biomass gasification using sacrificial tyre pyrolysis char," Appl. Energ. 190, 501-509. DOI: 10.1016/j.apenergy.2016.12.099

Arregi, A., Amutio, M., Lopez, G., Bilbao, J., and Olazar, M. (2018). "Evaluation of thermochemical routes for hydrogen production from biomass: A review," Energ. Convers. Manage. 165, 696-719. DOI: 10.1016/j.enconman.2018.03.089

GB/T 212 (2008). "Proximate analysis of coal," Standardization Administration of China, Beijing, China.

Han, J., and Kim, H. (2008). "The reduction and control technology of tar during biomass gasification/pyrolysis: An overview," Renew. Sust. Energ. Rev. 12(2), 397-416. DOI: 10.1016/j.rser.2006.07.015

He, M., Hu, Z., Xiao, B., Li, J., Guo, X., Luo, S., Yang, F., Feng, Y., Yang, G., and Liu, S. (2009). "Hydrogen-rich gas from catalytic steam gasification of municipal solid used (MSW): Influence of catalyst and temperature on yield and product composition," Int. J. Hydrogen Energ. 34(1), 195-203. DOI: 10.1016/j.ijhydene.2008.09.070

He, Y., Lin, H., Dong, Y., Li, B., Wang, L., Chu, S., Luo, M., and Liu, J. (2018). "Zeolite supported $\mathrm{Fe} / \mathrm{Ni}$ bimetallic nanoparticles for simultaneous removal of nitrate and phosphate: Synergistic effect and mechanism," Chem. Eng. J. 347, 669-681. DOI: 10.1016/j.cej.2018.04.088

Hu, M., Laghari, M., Cui, B., Xiao, B., Zhang, B., and Guo, D. (2018). "Catalytic cracking of biomass tar over char supported nickel catalyst," Energy 145, 228-237. DOI: 10.1016/j.energy.2017.12.096

Hu, S., Jiang, L., Wang, Y., Su, S., Sun, L., Xu, B., He, L., and Xiang, J. (2015). "Effects of inherent alkali and alkaline earth metallic species on biomass pyrolysis at different temperatures," Bioresource Technol. 192, 23-30. DOI: 10.1016/j.biortech.2015.05.042 
Kunkes, E. L., Simonetti, D. A., West, R. M., Serrano-Ruiz, J. C., Gärtner, C. A., and Dumesic, J. A. (2008). "Catalytic conversion of biomass to monofunctional hydrocarbons and targeted liquid-fuel classes," Science 322(5900), 417-421. DOI: 10.1126/science. 1159210

Liu, H., Chen, T., Zhang, X., Li, J., Chang, D., and Song, L. (2010). "Effect of additives on catalytic cracking of biomass gasification tar over a nickel-based catalyst," Chinese J. Catal. 31(4), 409-414. DOI: 10.1016/s1872-2067(09)60061-9

Liu, W.-J., Zeng, F.-X., Jiang, H., and Zhang, X.-S. (2011). "Preparation of high adsorption capacity bio-chars from used biomass," Bioresource Technol. 102(17), 8247-8252. DOI: 10.1016/j.biortech.2011.06.014

Mazumder, J., and De Lasa, H. I. (2014). "Ni catalysts for steam gasification of biomass: Effect of $\mathrm{La}_{2} \mathrm{O}_{3}$ loading," Catal. Today 237, 100-110. DOI: 10.1016/j.cattod.2014.02.015

Paethanom, A., Nakahara, S., Kobayashi, M., Prawisudha, P. and Yoshikawa, K. (2012). "Performance of tar removal by absorption and adsorption for biomass gasification," Fuel Process. Technol. 104, 144-154. DOI: 10.1016/j.fuproc.2012.05.006

Paethanom, A., Bartocci, P., D’ Alessandro, B., D’ Amico, M., Testarmata, F., Moriconi, N., Slopiecka, K., Yoshikawa, K., and Fantozzi, F. (2013). "A low-cost pyrogas cleaning system for power generation: Scaling up from lab to pilot," Appl. Energy 111, 1080-1088. DOI: 10.1016/j.apenergy.2013.06.044

Shen, Y., Wang, J., Ge, X., and Chen, M. (2016). "By-products recycling for syngas cleanup in biomass pyrolysis - An overview," Renew. Sust. Energ. Rev. 59, 12461268. DOI: 10.1016/j.rser.2016.01.077

Shen, Y., Zhao, P., Shao, Q., Ma, D., Takahashi, F., and Yoshikawa, K. (2014). "In-situ catalytic conversion of tar using rice husk char-supported nickel-iron catalysts for biomass pyrolysis/gasification," Appl. Catal. B Environ. 152-153, 140-151. DOI: 10.1016/j.apcatb.2014.01.032

Sienkiewicz-Gromiuk, J., Rusinek, I., Kurach, Ł., and Rzączyńska, Z. (2016). "Thermal and spectroscopic (IR, XPS) properties of lanthanide(III) benzene-1,3,5-triacetate complexes," J. Therm. Anal. Calorim. 126(1), 327-342. DOI: 10.1007/s10973-0165521-8

Sikarwar, V. S., Zhao, M., Clough, P., Yao, J., Zhong, X., Memon, M. Z., Shah, N., Anthony, E. J., and Fennell, P. S. (2016). "An overview of advances in biomass gasification," Energ. Environ. Sci. 9(10), 2939-2977. DOI: 10.1039/c6ee00935b

Valderrama Rios, M. L., González, A. M., Lora, E. E. S., and Almazán del Olmo, O. A. (2018). "Reduction of tar generated during biomass gasification: A review," Biomass Bioenerg. 108, 345-370. DOI: 10.1016/j.biombioe.2017.12.002

Xie, Y., Su, Y., Wang, P., Zhang, S., and Xiong, Y. (2018). "In-situ catalytic conversion of tar from biomass gasification over carbon nanofibers- supported Fe-Ni bimetallic catalysts," Fuel Process. Technol. 182, 77-87. DOI: 10.1016/j.fuproc.2018.10.019

Yamashita, T., and Hayes, P. (2008). "Analysis of XPS spectra of $\mathrm{Fe}^{2+}$ and $\mathrm{Fe}^{3+}$ ions in oxide materials," Appl. Surf. Sci. 254(8), 2441-2449. DOI: 10.1016/j.apsusc.2007.09.063

Yang, Y., Zhu, J., Zhu, G., Yang, L., and Zhu, Y. (2018). "The effect of high temperature on syngas production by immediate pyrolysis of wet sewage sludge with sawdust," $J$. Therm. Anal. Calorim. 132(3), 1783-1794. DOI: 10.1007/s10973-018-7143-9

Yao, D., Hu, Q., Wang, D., Yang, H., Wu, C., Wang, X., and Chen, H. (2016). "Hydrogen production from biomass gasification using biochar as a catalyst/support," 
Bioresource Technol. 216, 159-164. DOI: 10.1016/j.biortech.2016.05.011

Zeng, J., Xiao, R., Zhang, H., Chen, X., Zeng, D., and Ma, Z. (2017). "Syngas production via biomass self-moisture chemical looping gasification," Biomass Bioenerg. 104, 17. DOI: $10.1016 /$ j.biombioe.2017.03.020

Zhu, J., Yang, Y., Yang, L., and Zhu, Y. (2018). "High quality syngas produced from the co-pyrolysis of wet sewage sludge with sawdust," Int. J. Hydrogen Energ. 43(11), 5463-5472. DOI: 10.1016/j.jijhdene.2018.01.171

Article submitted: July 2, 2019; Peer review completed: November 30, 2019; Revised version received and accepted: April 16, 2020; Published: April 20, 2020.

DOI: 10.15376/biores.15.2.4294-4313 